\title{
Can we predict who will complete outpatient therapy for anorexia nervosa?
}

\author{
Jennifer Jordan ${ }^{1,2^{*}}$, Virginia McIntosh ${ }^{2,3}$, Frances Carter ${ }^{2}$, Peter Joyce ${ }^{1}$, Cynthia Bulik ${ }^{3,4}$, Suzanne Luty ${ }^{1}$, \\ Janice McKenzie ${ }^{1}$, Christopher Frampton ${ }^{1}$, Janet Carter $^{5}$ \\ From 2015 ANZAED Conference: Riding the Waves to Recovery \\ Surfers Paradise, Australia. 21-22 August 2015
}

The literature on characteristics associated with premature termination of treatment (PTT) is beset with conflicting findings.

\section{Aim}

This study examines potential clinical and therapy related predictors in relation to treatment completion status in a randomised psychotherapy trial for anorexia nervosa (AN).

\section{Methods}

Participants were 56 women aged 17-40 years with strict or lenient AN. Treatment completion was defined as completing 15/20 planned sessions. Measures were demographic and clinical variables (eating disorder history, comorbidity and personality measures), patient-rating on the Treatment Credibility scale and early therapy alliance audiotaped sessions were rated by independent raters using the Vanderbilt Therapeutic Alliance scale (VTAS) and the Vanderbilt Psychotherapy Process Scale (VPPS). Statistics were univariate tests, correlations and logistic regressions.

\section{Results}

Lower self-transcendence scores on the Temperament and Character Inventory, lower treatment credibility ratings and lower therapy alliance on some subscales were associated with PTT.

\section{Conclusions}

Paying close attention to specific patient personality characteristics, patient views of therapy and early process indicators may assist clinicians to retain more patients in treatment and thereby enhance treatment outcomes.

* Correspondence: jenny.jordan@otago.ac.nz

${ }^{1}$ University of Otago, New Zealand

Full list of author information is available at the end of the article
Authors' details

${ }^{1}$ University of Otago, New Zealand. ${ }^{2}$ Canterbury District Health Board, Christchurch, New Zealand. ${ }^{3}$ University of North Carolina at Chapel Hill, USA. ${ }^{4}$ The Karolinka Institute, Sweden. ${ }^{5}$ University of Canterbury, New Zealand.

Published: 23 November 2015

doi:10.1186/2050-2974-3-S1-O42

Cite this article as: Jordan et al.: Can we predict who will complete outpatient therapy for anorexia nervosa? Journal of Eating Disorders 2015 3(Suppl 1):O42.
Submit your next manuscript to BioMed Central and take full advantage of:

- Convenient online submission

- Thorough peer review

- No space constraints or color figure charges

- Immediate publication on acceptance

- Inclusion in PubMed, CAS, Scopus and Google Scholar

- Research which is freely available for redistribution

Submit your manuscript at www.biomedcentral.com/submit
() Biomed Central 